\title{
Pemberdayaan Ibu Rumah Tangga Dalam Upaya Peningkatan Kesejahteraan Keluarga Dengan Memanfaatkan Limbah Pohon Pisang
}

\author{
Empowerment Housewife in the Family Welfare Improvement Efforts by Using \\ Waste of Banana Tree
}

\author{
Asah Wiari Sidiq*, Asih Niati, Citra Rizkiana, Soedarmadi \\ Fakultas Ekonomi, Universitas Semarang \\ Kota Semarang - Indonesia \\ *asah.wiari77@gmail.com
}

Riwayat Artikel: Dikirim 16 Januari 2020; Diterima 15 Mei 2020; Diterbitkan 20 Mei 2020

\begin{abstract}
Abstrak
Potensi pohon pisang yang ada di wilayah perumahan Bukit Kencana sangatlah tinggi tetapi masyarakat sekitar hanya memanfaatkan pohon pisang terbatas pada buah dan daunnya saja, sedangkan limbahnya hanya dibiarkan sampai membusuk. Permasalahan yang timbul adalah aroma yang tidak sedap dari pembusukan sangat mengganggu masyarakat. Padahal limbah pohon pisang seperti bonggol pisang mempunyai kandungan gizi dan serat sangat tinggi dan dapat dimanfaatkan untuk konsumsi. Tujuan Pengabdian kepada Masyarakat memberikan tambahan pengetahuan dan ide kreatif untuk membuka minset berwirausaha sehingga dapat meningkatkan kualitas sumber daya manusia bagi ibu-ibu anggota PKK di Perumahan Bukit Kencana Jaya. Metode pelaksanaan kegiatan melalui penyuluhan atau ceramah, latihan pengolahan keripik, diskusi dan tanya jawab, yang diawali dengan memberikan pengetahuan mengenai kewirausahaan dalam mencari peluang usaha dengan potensi alam yang ada disekitar lingkungan perumahan Bukit Kencana Jaya. Dengan diadakan kegiatan pengabdian masyarakat ini dapat menambah pengetahuan akan manfaat bonggol pisang menjadi makanan sehingga dapat dikonsumsi atau dijualbelikan ke masyarakat lain dan akhirnya akan menambah penghasilan keluarga dan kesejahteraan keluar akan meningkat.
\end{abstract}

Kata kunci: Pemberdayaan Ibu Rumah Tangga, Limbah Pohon Pisang, Peningkatan Kesejahteraan Keluarga.

\begin{abstract}
The potential of banana trees in the Bukit Kencana housing area of Meteseh Village is very high but the surrounding community only uses banana trees limited to fruit and leaves, while the waste is only left to rot. The problem that arises is the unpleasant odor of decay is very disturbing to the community. Though banana tree waste such as banana stem has very high nutritional and fiber content and it can be used for consumption. The objective of Community Service is to provide additional knowledge and creative ideas to open an entrepreneurial mindset so that it can improve the quality of human resources for PKK members in Bukit Kencana Jaya Housing. The method of implementing activities are by giving counseling or lectures, practicing for processing chips, discussions and questions and answers, which begins with providing knowledge about entrepreneurship in looking for business opportunities with natural potential that are available around the Bukit Kencana Jaya housing environment. By organizing the community service activities, it can increase entrepreneurial knowledge and increase insight into how to use and process banana stem into food that can be consumed or sold to other communities so that it will increase income while increasing family welfare.
\end{abstract}

Keywords: Empowerment of Housewives, Banana Tree Waste, Increasing Family Welfare

\section{PENDAHULUAN}

Keluarga adalah kelompok inti yang ada dimasyarakat yang terbentuk dari suatu ikatan sakral dari sebuah perkawinan sehingga dapat terbentuk satu kelompok baru yang terdiri dari ayah, ibu dan anak.
Dalam kedudukannya ayah sebagai kepala keluarga dan istri sebagai pengelola manajemen keluarga. Keluarga mempunyai peran penting dalam meningkatkan kesejahteraan dan merupakan sumber daya manusia yang harus dikerahkan untuk 
mendapatkan penghasilan melalui berbagai aktifitas (Nugroho, 2018), sehingga terjadi peningkatan kualitas hidup dalam suatu keluarga.

Peran seorang istri sebagai menteri dalam pengelolaan manajemen keluarga sangat mempengaruhi sukses atau tidaknya kesejahteraan yang ada dikeluarga itu sendiri, oleh karena itu diperlukan kecerdasan seorang istri dalam mengelola keuangan keluarga sehingga dapat memberikan kebahagiaan bagi keluarga itu sendiri.

Menurut (Harum, 2017), dalam rangka meningkatkan kesejahteraan keluarga seorang istri tidak harus tergantung dari pendapatan suami namun harus melakukan kiat-kiat khusus bagaimana melakukan pengelolaan terhadap pendapatan yang diterima untuk kesejahteraan keluarga, oleh karena perlu bersama-sama suami meningkatkan kesejahteraan keluarga dengan pemahaman pengetahuan bagaimana upaya mendapatkan penghasilan untuk kebahagiaan hidup keluarga yang diharapkan.

Salah satu upaya yang dilakukan adalah melakukan pemberdayaan para ibu rumah tangga guna mengembangkan kemandirian dan kesejahteraan masyarakat melalui upaya peningkatan knowladge, skill dan perilaku serta jiwa wirausaha sehingga dapat membantu pemerintah dalam mengatasi permasalahan sosial yang ada dimasyarakat.

Kelurahan Meteseh merupakan wilayah yang berada di kecamatan Tembalang dengan luas $\pm \mathbf{8 5 5 , 8 3 8} \mathbf{H a}$ dimana telah dibatasi oleh beberapa wilayah yaitu : kelurahan Mangunharjo dan kelurahan Sendang Mulyo (sebelah utara), kelurahan Rowosari (sebelah Timur), kelurahan Jabungan (sebelah selatan) dan kelurahan Bulusan (sebelah barat).

Menurut

(http:/meteseh.

Semarangkota.go.id, 2018 dilihat dari demografi bahwa jumlah penduduk di Wilayah Meteseh sebesar 20.374 jiwa dan wilayah Kelurahan Meteseh merupakan wilayah yang terus berkembang yang didominasi oleh penduduk yang tinggal di perumahan. Salah satu perumahan yang ada di wilayah Meteseh adalah perumahan Bukit Kencana Jaya yaitu suatu kawasan pengembangan perumahan yang jumlah penduduknya sangat banyak dimana berdasarkan survey terbaru untuk jumlah kepala keluarga yang ada di Bukit Kencana Jaya saja sudah mencapai 3.000 kepala keluarga.

Seperti yang dirasakan oleh masyarakat lainnya bahwa pada umumnya sebagian besar perekonomian penduduk di perumahanan Bukit Kencana Jaya sudah dalam taraf hidup sejahtera dimana secara minimal sudah dapat memenuhi kebutuhan dasar, namun masih ada beberapa yang belum dapat memenuhi keseluruhan kebutuhan sekunder berupa kebutuhan sosial. Untuk memenuhi kebutuhan sosialnya berusaha melakukan pinjaman melalui berbagai cara seperti pinjaman simpan pinjam di PKK wilayah masingmasing, kredit konvensional yang selalu beredar di sekitar wilayah Bukit Kencana Jaya dengan sasaran masyarakat yang mempunyai perekonomian kelas menengah ke bawah dan yang lebih parah lagi terjeratnya oleh kaum rentenir. Apabila hal ini tidak didukung dari pendapatan lain maka akan sangat mungkin terjadi penurunan status kesejahteraan dan yang lebih ironis akan berdampak pada keharmonisan keluarga, oleh karena itu dalam upaya membantu pendapatan suami dan mencukupi kebutuhan sosialnya maka perlu dilakukan pemberdayaan kepada ibu rumah tangga yang ada di wilayah Bukit Kencana Jaya dengan menggunakan sumber daya alam yang dimiliki yang pada akhirnya dapat menghasilkan sesuatu yang bisa menambah penghasilan untuk memenuhi kebutuhan sosialnya.

Dilihat dari kondisi wilayah bahwa Perumahan Bukit Kencana Jaya masih banyak dikelilingi oleh tanaman pohon pisang dan pemanfaataannya oleh penduduk hanya diambil buahnya saja. 
Dilihat dari sisi ekonomi sosial masyarakat dan potensi sumber daya yang ada ternyata banyaknya tanaman pisang tumbuh tetapi belum dimanfaatkan secara maksimal, hal ini perlu adanya pengetahuan dan inovasi pengolahan pohon pisang yang dulunya hanya limbah yang tidak bermanfaat dapat menjadi bermanfaat, sehingga dapat dijadikan usaha sampingan maupun usaha utama untuk menambah penghasilan khususnya bagi ibu-ibu rumah tangga.

Dari segi memanfaatkan ternyata ada bagian lain dari pohon pisang yang dapat diolah menjadi sesuatu yang dapat menghasilkan produk makanan dengan nilai kandungan gizi yang baik, salah satunya adalah pemanfaatan bonggol pisang. Dahulu bonggol pohon pisang biasanya hanya dianggap sebagai limbah yang didiamkan saja hingga membusuk sehingga menimbulkan aroma yang tidak enak, tetapi ada beberapa masyarakat yang mempunyai inisiatif untuk memanfaatkan bonggol pisang menjadi pakan ternak.

\section{Permasalahan Mitra}

Berdasar hasil analisa situasi yang telah dipaparkan di atas ditemukan identifikasi permasalahan mitra antara lain sebagai berikut :

1. Masih rendahnya pengetahuan ibu rumah tangga untuk melakukan kreatifitas usaha guna menambah atau membantu sumber penghasilan keluarga.

2. masih banyak pendapatan kepala keluarga yang belum bisa memenuhi standar kebutuhan hidup yang lebih baik karena rendahnya taraf hidup, tingkat pendidikan, dan pekerjaan sehingga akan menimbulkan permasalahan social.

3. Banyak ibu rumah tangga yang tidak bekerja terlilit hutang dengan bank konvensional .

4. Banyaknya sumber daya alam yang ada diwilayah tersebut belum dimanfaatkan terutama pada sumber daya alam yang ada berupa bonggol pisang pohon pisang.

Dilihat dari hasil permasalahan diatas maka tim pengusul pengabdian akan mengadakan kegiatan pengabdian kepada masyarakat dalam bentuk penyuluhan dan pelatihan bagaimana mencari peluang usaha dengan memberdayakan penduduk yang ada di Kelurahan Bukit Kencana Jaya dalam bentuk pembuatan produk makanan dari bonggol pohon pisang. Dalam usulan pengabdian ini tim pengabdian lebih menekankan kepada ibu-ibu PKK yang ada di Perumahan Bukit Kencana Jaya melalui penyuluhan dan pelatihan wirausaha sehingga dapat menambah penghasilan .

\section{METODE}

\section{Pelaksanaan}

Metode pelaksanakan kegiatan pengabdian ini berupa penyuluhan, pelatihan, diskusi dan tanya jawab, dimana tim pengabdian mengawali kegiatan dengan memberikan pengetahuan mengenai kewirausahaan dalam mencari peluang usaha dengan potensi alam yang ada disekitar lingkungan perumahan Bukit Kencana Jaya, kemudian melakukan Pelatihan berupa pembuatan pengolahan makanan cemilan dari bonggol pohon pisang.

\section{Evaluasi}

Evaluasi hasil kegiatan pengabdian kepada masyarakat dilakukan dengan membandingkan keadaan peserta sebelum dan setelah kegiatan dengan cara membagikan kuesioner pre test dan post test serta tanya jawab mengenai kegiatan ini. Keberhasilan kegiatan ditujukan dengan adanya perubahan positif dari keadaan peserta yaitu adanya peningkatan pemahaman dan pengetahuan mengenai kewirausahaan, peluang usaha dengan memanfaatkan potensi alam yang ada.

HASIL DAN PEMBAHASAN Hasil Yang Dicapai 
Kegiatan Pengabdian Kepada Masyarakat dilaksanakan di Wilayah Perumahan Bukit Kencana tepatnya di jalan Bukit Kelapa Raya blok BB Kelurahan Meteseh Kecamatan Tembalang Kota Semarang - Jawa Tengah pada hari Sabtu tanggal 30 November 2019 dengan peserta dari kelompok PKK warga perumahan Bukit Kencana Jaya.

Pelaksanaan kegiatan tersebut diawali dengan perkenalan dan maksud dari tujuan melakukan pengabdian kemudian memberikan pengetahuan dan pelatihan berwirausaha dengan memanfaatkan dan mengolah bonggol pisang menjadi keripik bonggol pisang.

\section{Evaluasi Kegiatan Pengabdian Kepada Masyarakat}

Kegiatan pengabdian kepada masyarakat bagi ibu-ibu rumah tangga di wilayah bukit kencana Kel. Meteseh Kota Semarang telah berjalan dengan lancar dan para peserta telah mengikuti seluruh program pengabdian dengan bersemangat mulai dari pembukaan sampai kegiatan berakhir. Hal ini dapat dilihat pada feed back dari peserta dengan adanya respon dan tanya jawab serta permintaan untuk mengisi kembali. Berikut foto kegiatan pengabdian kepada masyarakat:

Gambar 1:

Kegiatan Pengabdian Masyarakat

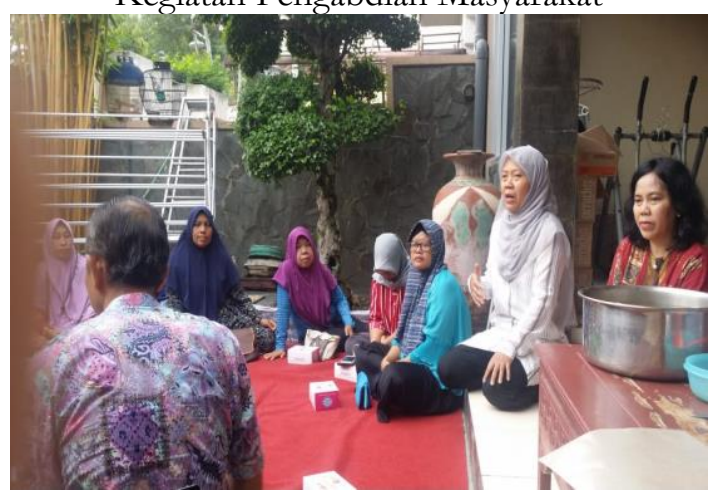

Sumber: Dokumentasi Pribadi
Kegiatan Pengabdian Masyarakat

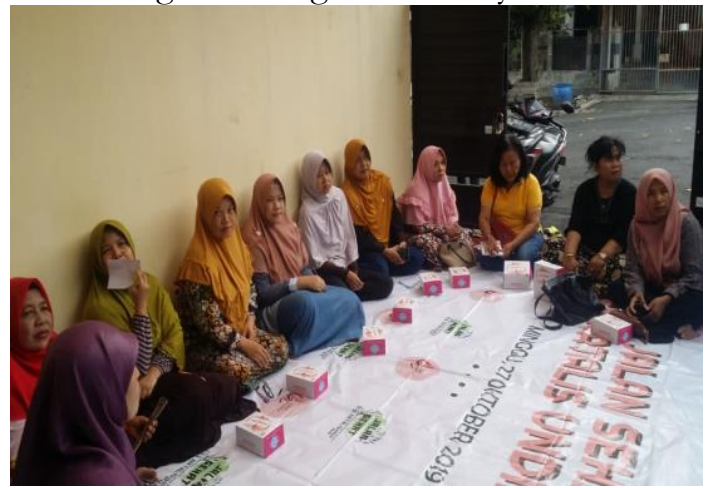

Sumber: Dokumentasi Pribadi

Gambar 3:

Kegiatan Pengabdian Masyarakat

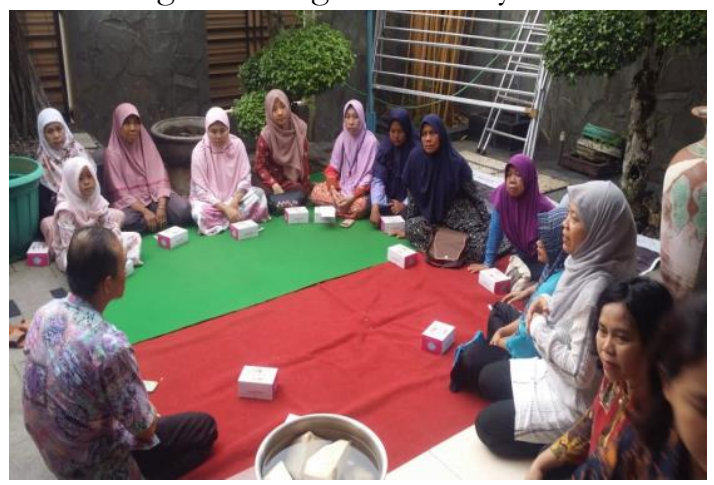

Sumber: Dokumentasi Pribadi

\section{KESIMPULAN}

\section{Kesimpulan}

Kegiatan Pengabdian kepada masyarakat yang dilaksanakan oleh tim Fakultas Ekonomi Universitas Semarang telah berjalan sesuai rencana yang dihadiri oleh 21peserta dari ibu-ibu PKK Perumahan Bukit Kencana Jaya Kel. Meteseh Kec. Tembalang Kota Semarang sehingga peserta mendapatkan motivasi berwirausaha, adanya peningkatan pemahaman peserta tentang kewirausahaan serta bertambahnya pengetahuan mengenai manfaat bonggol pisang dan cara mengolah bonggol pisang menjadi makanan baik untuk camilan maupun untuk dijual. 
Peserta perlu mendapat dukungan dan motivasi dari pemerintah untuk memanfaatkan potensi lingkungan sekitar serta sebaiknya secara rutin mengaplikasikan membuat kripik bonggol pisang sehingga mempunyai cita rasa yang enak sehingga dapat dimanfaatkan untuk peluang berwirausaha.

\section{DAFTAR PUSTAKA}

Sukmawati, A. M. A., \& Yuliastuti, N. (2014). Efektivitas Pemanfaatan Fasilitas Sosial di Perumahan Bukit Kencana Jaya Semarang. Teknik PWK (Perencanaan Wilayah Kota), 3(3), 371381.

Nugraha, W. D., Suri, D. A., \& Syafrudin, S. Studi Potensi Pemanfaatan Nilai Ekonomi Sampah Anorganik melalui Konsep Daur Ulang dalam Rangka Optimalisasi Pengelolaan Sampah (Studi Kasus: Kota Magelang). Teknik, 28(1), 9-20.

Semarang, K. (2019). Geografis dan Penduduk. Retrieved September 2, 2019, from https://meteseh.semarangkota.go.id/g eografisdanpenduduk

Organisasi (2012). Isi Kandungan Gizi Bonggol Pisang - Komposisi Nutrisi Bahan Makanan. Retrieved September, 2019, from http://www.organisasi.org/1970/01/i si-kandungan-gizi-bonggol-pisangkomposisi-nutrisi-bahanmakanan.html

Nugroho, M. T. (2018). Peran Ibu Rumah Tangga dalam Meningkatkan Kesejahteraan Keluarga. (Socio Informa), 4(2), 418-436.

Nurita, R.F. (2016). Upaya Pemberdayaan Ibu Rumah Tangga di Desa Kalirejo Lawang Dengan Tujuan Memotivasi Kewirausahaan Mandiri. Jurnal Abdimas UNMER), 1(2), 1(2), 47-53.

Rakhmawati. (2016). Pemanfaatan Bonggol Pisang Menjadi Stick Nugget. (Pengabdhi), 44-51. 